\title{
ALGEPS
}

REVISTA DE GEOLOGIA, SĖRIE B no 631 - Maig del 2013

\section{RECORREGUT DE RECERCA GEOLÒGICA I MINERALÒGICA PER LES COMARQUES DE LA LLITERA I DE LA BAIXA RIBAGORÇA: DES TAMARIT DE LLITERA A CAMPORRELS I A PURROI DE LA SOLANA}

Josep M. Mata-Perelló i Joaquim Sanz Balagué 


\section{RECORREGUT DE RECERCA GEOLÒGICA I MINERALÒGICA PER LES COMARQUES DE LA LLITERA I DE LA BAIXA RIBAGORÇA: DES TAMARIT DE LLITERA A CAMPORRELS I A PURROI DE LA SOLANA ${ }^{1}$}

Per Josep M. Mata-Perelló i Joaquim Sanz Balagué

\section{ADVERTIMENTS PREVIS}

Com en altres recorreguts de RECERCA GEOLÒGICA I MINERALÒGICA ..., si es disposa del temps suficient, poden efectuar-se passant per totes les parades i filloles. En cas contrari, recomanem prescindir de les anomenades PARADES - CONDICIONALS.

També cal tenir en conte que una part del recorregut final de l'itinerari, es realitzarà per camins de terra, per la qual cosa caldrà prendre les degudes precaucions. Així, d'aquesta manera es circularà entre les poblacions d'Estanya y Estopanyà, totalment dintre de la comarca de la Baixa Ribagorça.

Cal tenir, com sempre, una cura molt especial de respecte a la natura, al llarg de tot el recorregut de l'itinerari, i també fora d'ell.

\section{BREU INTRODUCCIÓ}

En aquesta ocasió, tot i que el recorregut de l'itinerari s'iniciarà a la Depressió Geològica de l'Ebre (i més concretament a la denominada Zona de l'Avant-País Plegat). Tanmateix una bona part del mateix discorrerà pel Sistema Pirinenc (o més exactament per la seva Unitat Central Sudpirenenca).

El recorregut s'iniciarà a la població de Tamarit de Llitera, dintre dels sectors marginals de la Depressió Geològica de l'Ebre (i més concretament a la Zona de l'Avant-País Plegat), per la qual es circularà entre la mateixa localitat d'Alfarràs i la de Natjà. En aquest trànsit, es tallarà l'important Anticlinal de Balaguer-Alfarràs-Barbastro.

Finalment, el darrer tram del recorregut s'efectuarà pel Sistema Pirinenc, entre l'esmentada població de Natjà i Benavarri, la capital de l'antiga comarca de la Baixa Ribagorça (ara integrada dintre de la comarca de la Ribagorça). Estopanyà. En aquest recorregut, es

\footnotetext{
${ }^{1}$ En este escrito se ha optado por utilizar los nombres de los topónimos en las modalidades dialectales utilizadas en la zona. Sin embargo, al final (tras la bibliografía) se ha colocado un esquema de equivalencias entre el nombre utilizado y el castellano, de uso común en Aragón. Así: VER: APENDIX TAULA D’EQUIVALÈNCIES DELS TERMES TOPONÓMICS DE LA ZONA (PAG. 16)
} 
discorrerà bàsicament per la Unitat de les Serres Marginals.

Per d'altra banda, el recorregut transitarà per diverses comarques de l'àrea econòmica i geogràfica de Lleida. Així, després d'iniciar-se a la localitat de Tamarit de Llitera, es transitarà per comarca de la Llitera, fins arribar a Natjà. Finalment, s'entrarà a la comarca de la Baixa Ribagorça, per on es transitarà entre el Coll de Saganta i la població de Purroi de la Solana, per on finalitzarà el recorregut de l'itinerari.

\section{OBJECTIUS GENERALS D’AQUEST ITINERARI}

En aquest itinerari, els objectius generals, que s'han d'aconseguir, es poden concretar en els següents aspectes:

1.- Estudi i reconeixement dels materials cenozoics (fonamentalment de l'Oligocè) situats a la Depressió Geològica de l'Ebre, que tallarem entre Tamarit de Llitera i Natjà, tot passant per Alcampell i Baells. En la seva major part, aquests materials pertanyen als guixos de la "Formació Barbastro", a les lutites i gresos de la "Formació Peralta", i als nivells detrítics de la "Formació Peraltilla" i del "Conglomerats de Baells".

2.- Observació de l'estructura de la Depressió Geològica de l'Ebre, que dintre d'aquest itinerari trobarem. Així, el recorregut s'iniciarà a la Zona de l'Avant-País Plegat, per la qual es transitarà fins arribar a Natjà.

3.- Estudi i reconeixement dels materials mesozoics (del Triàsic i del Cretàcic, fonamentalment), situats a les Serres Meridionals Prepirinenques, i més concretament al Mantell de la Unitat de les Serres Marginals, i que trobarem pels voltants de Natjà i Purroi de la Solana, al final del recorregut.

4.- Observació de l'estructura de les Serres Meridionals Prepirinenques, i de les seves relacions amb la Depressió Geològica de l'Ebre (o més exactament, amb la Zona de l'AvantPaís Plegat).

5.- Estudi i descripció de diverses mineralitzacions situades al llarg del recorregut de l'itinerari, entre les quals destacarem les mineralitzacions manganesíferes de rebliments de cavitats d'origen càrstic, situades entre les calcàries cretàciques, i que es troben a les localitats de Natjà i de Purroi de la Solana.

6.- Visió d'algunes de les explotacions relacionades amb les mineralitzacions anteriors; així com les relacionades amb els afloraments de guixos.

7.- Observació de la zona de les llacunes d'Estanya, d'origen kàrstic, situat entre les poblacions d'Estanya i Casserres del Castell.

8.- Visió dels diferents indrets directament relacionats amb el Patrimoni Geològic i Miner, situats a la bora del recorregut d'aquest itinerari. 


\section{ANTECEDENTS BIBLIOGRÀFICS}

En relació amb aquest itinerari geològico-mineralògic, existeixen diversos antecedents bibliogràfics nostres (MATA-PERELLÓ 1991b, 1995, 1996, 1997, 1998, 2002, 2003, 2005, 2007, 2009 i 2010). Es tracta de diferents itineraris que discorren per aquestes mateixes comarques, i en alguns casos pels mateixos indrets que el present, almenys en alguns trams del seus recorreguts.

Per d'altra banda, també farem esment de dos treballs, de caràcter geològic generalista, que corresponen a GUIMERA et altri (1992), i a RIBA et altri (1976). Ambdós fan referència al conjunt de la geologia dels Països Catalans. Tanmateix, farem esment dels treballs de 1'IGME (1974a i 1974b), relatius al Mapa Metalogenético de España.

I, pel que fa a les mineralitzacions situades en aquestes comarques, farem esment del treball de CALVO et altri (1988); així com de diversos treballs nostres; concretament dels següents: MATA-PERELLÓ $(1979,1985,1990 \mathrm{a}, 1990 \mathrm{~b}$ i 1991a). Tanmateix farem esment d'uns altres treballs nostres, concretament de: MATA-PERELLÓ i SANZ BALAGUÉ (1989 i 1990).

Tots aquests treballs, i d'altres, figuraran esmentats, per ordre alfabètic, a l'apartat dedicat a les REFERÈNCIES BIBLIOGRÀFIQUES.

\section{RECORREGUT DE L' ITINERARI}

S '́niciarà a la comarca de la Llitera, i més concretament a la localitat de Tamarit de Llitera, per on es faran diverses aturades. En aquesta darrera població caldrà seguir per la carretera d'Alcampell. Abans d'arribar a aquesta darrera població es faran dues noves aturades.

Després, el recorregut continuarà cap al Nord-Est, arribant-se a la carretera N-230, per tal de seguir cap al Nord. Així, es passarà ara per Baells. Després el recorregut es dirigirà cap a Natjà, per on es faran diverses aturades. Tot seguit anirà cap a Camporrells, arribant-se després al Coll de Saganta, per on es farà una nova atura. En aquest recorregut es passarà de la comarca de la Llitera a la de la Baixa Ribagorça.

Tot seguit de passar el coll, caldrà continuar per la carretera N-230, arribant aviat a les immediacions de Purroi de la Solana, per on farem una nova aturada. Després, caldrà fer una fillola per la carretera que es dirigeix cap a Estopanyà, fins trobar el trencall (per l'esquerra), d'on surt la carretereta d'Estanya, que haurem d'agafar, per tal de continuar després per la que se'n va cap a Casserres del Castell. En aquest tram, poc després de sobrepassar Estanya, caldrà fer una aturada als Llacs d'Estanya.

Després, el recorregut retornarà cap a la carretera $\mathrm{N}-230$, per la qual es continuarà cap a la població de Purroi de la Solana, per on finalitzarà el recorregut de l'itinerari.

\section{DESCRIPCIÓ DE L'ITINERARI}


Com ja és habitual, farem una sèrie de PARADES (o de ESTACIONS). En cada una d'elles, farem esment del terme municipal on es troben (en el cas de que no quedi clar, al situar la parada), així com del número del MAPA TOPOGRÁFICO NACIONAL (a escala 1:50.000), que indicarem entre parèntesi. En aquesta ocasió, utilitzarem els següents full: 288 (dita de Fonz), 289 (dita de Benavarri), 326 (dita de Montsó / Monzón), 327 (dita d’Os de Balaguer) i 359 (dita de Balaguer).

Així, la relació ordenada de les parades que composen el recorregut d’aquest itinerari, és la següent:

PARADA 1. GESERA (GUIXERA) DE TAMARIT DE LLITERA, (terme municipal de Tamarit de Llitera, comarca de la Llitera). (Full 326).

El present recorregut, cal iniciar-lo a la població de Tamarit de Llitera, tot sortint per la carretera autonòmica A-1240, la qual es dirigeix cap Alcampell. Just a la sortida de Tamarit es farà la present aturada.

En aquest curt recorregut, s'han continuat trobant inicialment els materials de la Formació Peraltilla (sobre els que s'assenta la població); així, s' han anat tallant nivells ocres de gresos i calcolutites. Més endavant, en arribar a a l'indret de l'aturada, s' han fet clarament palesos els nivells guixosos, també oligocènics, de la Formació Barbastro. Aquests nivells, a l'igual que els anteriors, en aquest indret, es troben clarament afectats pels plecs de l'Anticlinal de Balaguer-Alfarràs-Barbastro, situant-se tot aquest conjunt dintre de l'Avant-país Plegat, on ara som.

També cal dir que els materials guixosos han estat explotats a diferents indrets, amb la intenció de beneficiar el GUIX, com a matèria prima per a diferents guixeres properes. FOTOGRAFIA 1.

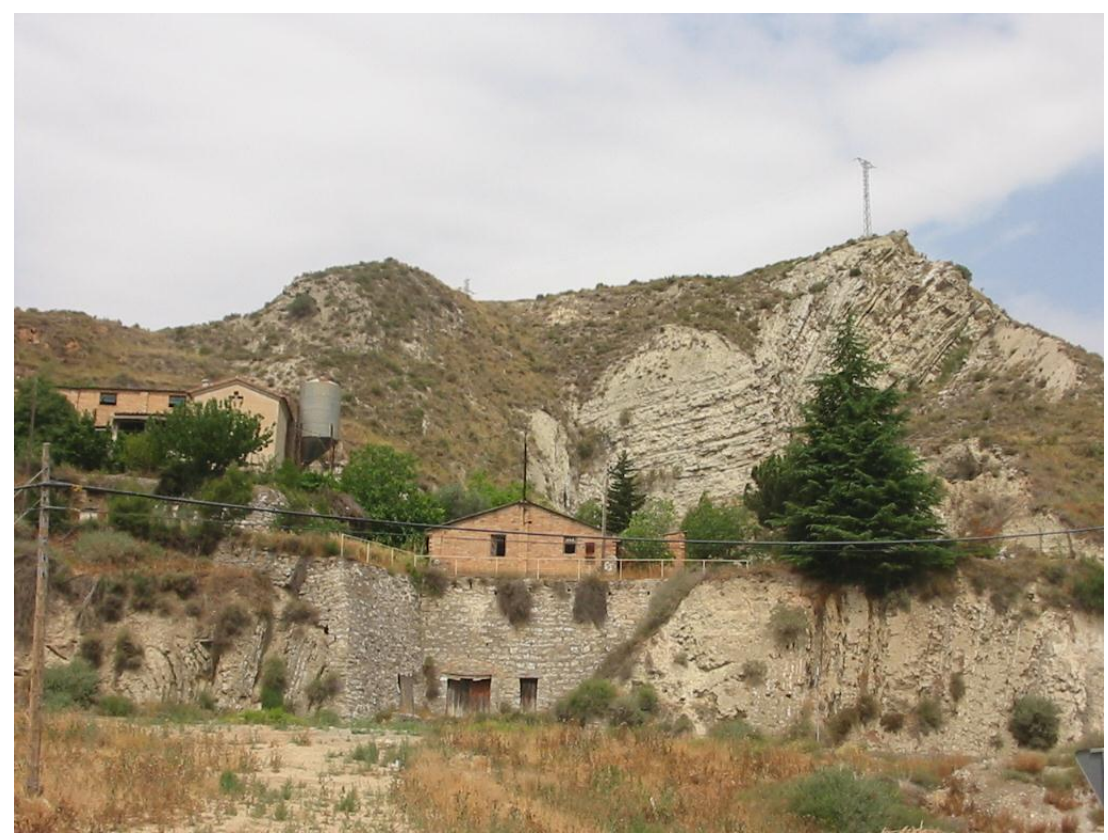

FOTOGRAFIA 1. 
Aspecte de la guixera de Tamarit de Llitera

PARADA 2. CARRETERA A-1240, CAP ALCAMPELL, A $2 \mathrm{Km} \mathrm{DE}$ TAMARIT DE LLITERA, (terme de Tamarit de Llitera, comarca de la Llitera). (Full 326).

Després de fer l'aturada anterior, cal fer un recorregut proper als $2 \mathrm{Km}$, per la carretera autonòmica A-1240. En aquest recorregut s'anirà des de Tamarit de Llitera cap a les immediacions del poble de lo Campell (Alcampell). Poc abans d'arribar-hi, a uns $2 \mathrm{Km}$ de Tamarit, caldrà fer una nova aturada.

En aquest recorregut, hem anat trobant afloraments dels materials cenozoics que formen part de la Depressió Geològica de l'Ebre, en concret del denominant Avant-país Plegat. Així, hem trobat els materials guixosos que formen part de l'anticlinal que hem trobat a la sortida de Tamarit. En bona part, aquests materials formen part de la denominada molt sovint com a Formació Barbastro, que ara a l'indret de l'aturada afloren per arreu.

Aquests materials es troben força plegats i replegats, com es pot observar amplament a l'indret de l'aturada. FOTOGRAFIA 2.

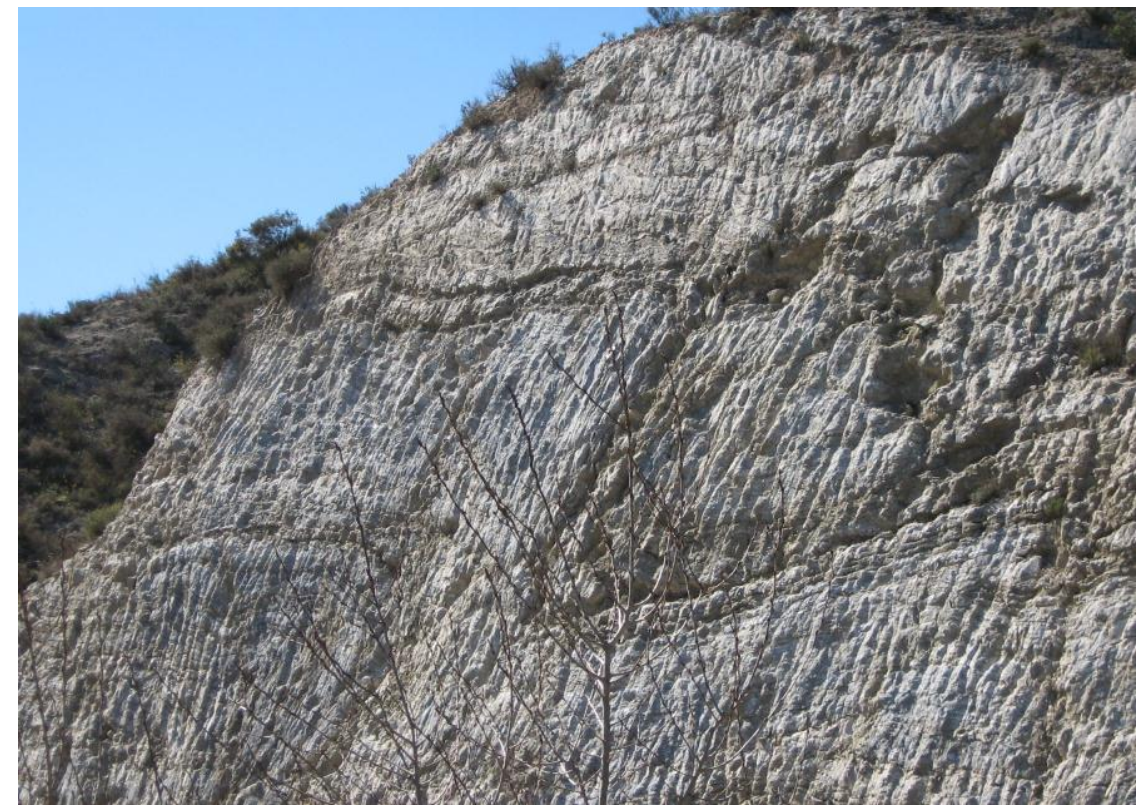

FOTOGRAFIA 2

Materials guixosos plegats i replegats

PARADA 3 - CONDICIONAL. CRUÏLLA DE LA CARRETERA D'ALCAMPELL (LA A-1240) AMB LA N-230, (terme municipal de lo Campell o Alcampell, comarca de la Llitera). (Full 326).

Després de fer l'aturada anterior, cal fer un recorregut proper als $10 \mathrm{Km}$. En aquest recorregut s'anirà des de Tamarit de Llitera cap al poble de lo Campell (que es creurà), dins a la cruïlla amb la carretera $N-230$. En arribar a les immediacions d'aquest indret es farà, si 
s'escau, una nova aturada.

En aquest recorregut, hem anat trobant afloraments dels materials cenozoics que formen part de la Depressió Geològica de 1'Ebre, en concret del denominant Avant-país Plegat. Així, hem trobat els materials guixosos que formen part de l'anticlinal que hem trobat a la sortida de Tamarit. En bona part, aquests materials formen part de la denominada molt sovint com a Formació Barbastro, que ara a l'indret de l'aturada tenim un xic al Sud, a Castillonroi.

Per d'altra banda, en aquest indret hi ha un interessant aflorament dels materials quaternaris que formen part d'una terrassa fluvial, creiem que del vell Essera. Aquests materials es troben força inclinats $i$ ens indiquen una vergència cap a ponent d'aquests materials, coincidint amb el canvi de rumb d'aquest riu.

\section{PARADA 4. SORTIDA DE NATJÀ CAP A CAMPORRELLS, (terme municipal de Natjà, comarca de la Llitera). (Full 327).}

Des de la parada anterior, cal continuar cap el poble de Baells, per la carretera N-230 (en el seu sentit septentrional), fins trobar la carretera que es dirigeix cap a Natjà. Aquesta carretera surt per la dreta segons el sentit de la marxa. Després, en arribar a Natjà, cal sortir per la carretera de Camporrells. A la mateixa sortida del poble farem aquesta aturada, a uns $10 \mathrm{Km}$ de l'anterior.

A la major part del trajecte, es van tallant els materials cenozoics oligocènics, amb nivells detrítics (sorrencs i conglomeràtics), que constitueixen els anomenats "Conglomerats de Baells". Tot i així, en aquest indret afloren els nivells lutítics i sorrencs de la Formació Peraltilla. Així, a l'indret de la parada, es fan presents aquests darrers materials de la Formació Peraltilla, els quals es troben aquí encavalcats pels materials mesozoics (del Triàsic Superior), del Mantell de la Unitat de les Serres Marginals. FOTOGRAFIA 3.

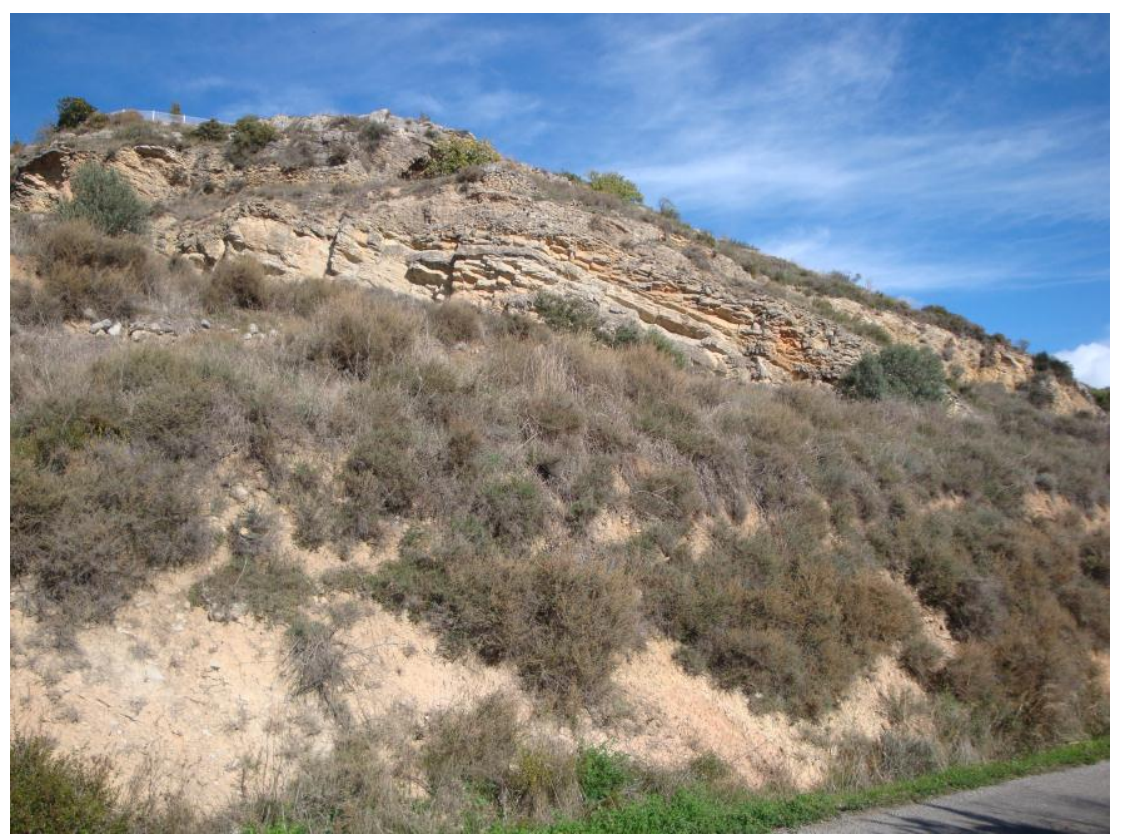

FOTOGRAFIA 3

Detall del contacte 
Entre els materials mesozoics del Keuper (del Triàsic Superior) es fan força palesos els guixos de color rogenc, molt típics, Tanmateix s'aprecien petits cristallets de "Jacints de Compostel·la" (QUARS bipiramidal de color rogenc, tot i que en aquest indret alguns son incolors). Entre els minerals presents, a més a més del GUIX, també cal parlar de les freqüents eflorescències d'EPSOMITA i HEXAHIDRITA.

\section{PARADA 5. CRUÏLLA DE LA CARRETERA AMB EL CAMÍ DE LA MINA DE MANGANÈS, (terme municipal de Natjà, comarca de la Llitera). (Full 327).}

Després de fer l'aturada anterior, cal fer un breu recorregut, de poc més de 150 metres, per tal de trobar el camí que es dirigeix cap a la Mina de Manganès de Natjà. Així, a l'inici del camí farem una nova aturada.

En aquest breu recorregut, he anat trobant fonamentalment els materials triàsics del Keuper, que ja hem vist a la parada anterior. Tot i així, a l'indret de l'aturada hi ha un interessant aflorament de les ofites del Keuper. Entre aquests materials es fan paleses unes minoritàries mineralitzacions d'AERENITA i de CAOLINITA. També es fa força present la MAGNETITA entre la pols de la roca, al adherir-se als imants.

PARADA 6. MINA DE MANGANÈS DE NATJÀ, (terme municipal de Natjà, comarca de la Llitera). (Full 327).

Després de fer l'aturada anterior, cal fer un altre breu recorregut, de poc més de 200 metres, per tal d'arribar a peu fins a la Mina de Manganès de Natjà. En arribar-hi farem una nova aturada.

En aquest breu recorregut, s'han anat tallant els materials mesozoics, del Triàsic. Prop de la mina, hi afloren uns nivells carbonatats del Cretàcic: concretament les "calcàries arenoses del Montsec". Precisament, la mineralització es situa sobre aquests calcàries cretàciques, tot reblint cavitats d'origen càrstic. FOTOGRAFIA 4. 


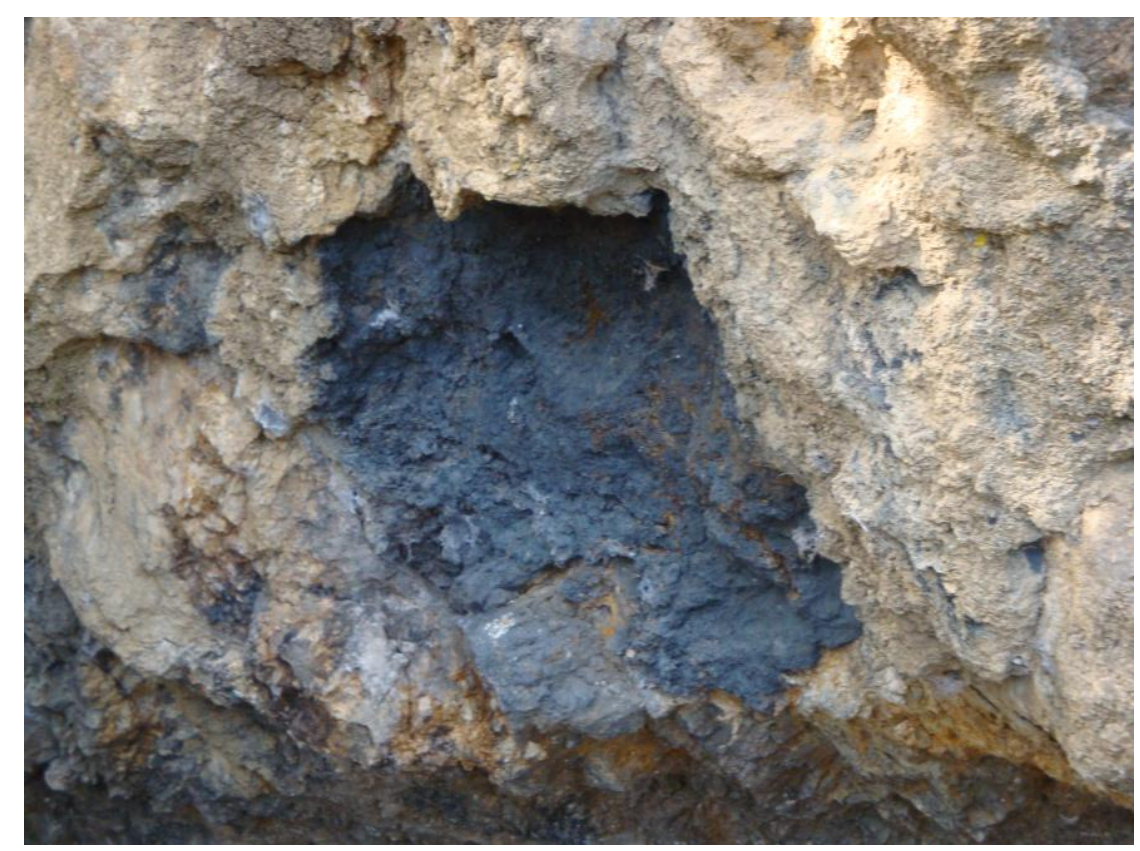

FOTOGRAFIA 4

Detall de la mineralització de manganès

Així, en arribar a l'indret de la parada, es fa palesa una interessant mineralització de rebliment de cavitats d'origen càrstic. Així, la mineralització, de caràcter magnesífer (i al mateix temps també de caràcter ferrífer), es troba situada entre els afloraments carbonatats acabats d'esmentar del Cretàcic.

Es tracta d'un rebliment de composició mineralògica de caràcter Mn-Fe; amb presència entre els minerals de manganès dels següents minerals: BIRNESSITA, PIROLUSITA (sense cap mena de dubte, és el mineral majoritari de l'indici), PSILOMELANA, RAMSDOLLITA (sempre molt minoritari), TODOROQUITA, MANGANOCALCITA i RODOCROISITA. Per d'altra banda, entre els minerals de ferro es troben els següents: GOETHITA (molt abundant, i sempre d'aspecte terrós, molt limonítica), HEMATITES (també molt abundant) i SIDERITA. També és molt abundant la CALCITA, sovint de color rosat.

PARADA 7. ENTRADA A CAMPORRELLS, (terme municipal de Camporrells, comarca de la Llitera). (Full 327).

Després de fer l'aturada anterior, cal tornar a la carretera. En trobar-la, cal fer un altre breu recorregut, de poc més de $4 \mathrm{Km}$, amb la intenció d'arribar a Camporrells. Just a l'entrada de la població farem una nova aturada.

En bona part d'aquest recorregut, hem anat trobant afloraments dels materials triàsics del Keuper, amb nivells de guixos i d'argiles, fonamentalment. Aquests són els materials que hi ha a l'indret de l'aturada. Just en aquest indret es fa pales un aflorament d'ofites, entre els materials del Keuper. En aquestes roques subvolcàniques es fan paleses unes interessants mineralitzacions d'AERINITA. Cal recordar que aquest mineral va ésser el que va proporcionar el color blau utilitzat a les pintures del romànic català. FOTOGRAFIA 5. 


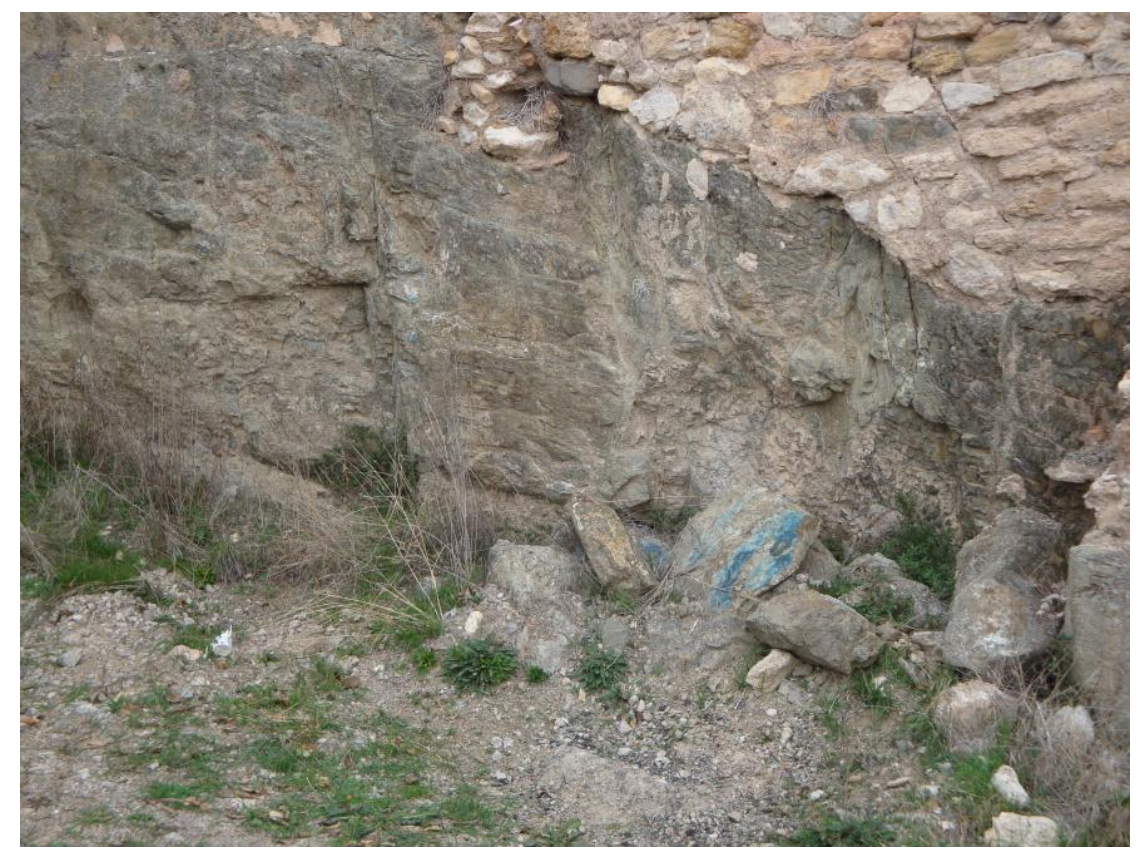

FOTOGRAFIA 5.

Detall de l'AERENITA

Per d'altra banda, en aquest indret hi ha un bon Pou de Gel, molt ben conservat. És un bon exemple d'aquest tipus de construccions.

PARADA 8 - CONDICIONAL. BALNEARI DE CAMPORRELLS, (terme municipal de Camporrells, comarca de la Llitera). (Full 327).

Des de l'aturada anterior cal continuar per la carretera, fent ara un breu recorregut (de menys de 0'2 Km), per tal d'arribar a l'antic Balneari de Camporrells, on podem fer una nova aturada, si s'escau

En aquest breu recorregut hem anat trobant els materials triàsics que ja hem trobat en el recorregut cap a la parada anterior. Aquests són també els materials que hi per arreu, pels voltants del poble, per on predominen els materials triàsics del Keuper.

En aquest indret hi ha unes fonts d'aigua sulfatada y carbonatada. Tradicionalment, aquestes aigües han estat explotades en un antic balneari, que actualment es troba tancat des de fa uns anys.

PARADA 9. COLL DE SAGANTA, (Saganta, terme municipal d’Estopanyà, comarca de la Baixa Ribagorça). (Full 327).

Després de fer l'aturada anterior cal seguir ara per la carretera A-2218, la qual es dirigeix cap Coll de Saganta, per on farem una nova aturada, a uns $5 \mathrm{Km}$ de la darrera.

En aquest recorregut, hem anat trobant afloraments dels materials quaternaris esmentats a la parada anterior. Així, per arreu trobarem afloraments dels trams argilosos i guixosos del Keuper (del Triàsic Superior). 
Des d'aquest indret, es pot veure una interessant panoràmica dels Pirineus, especialment del Montsec. Tanmateix es pot veure la boca sud de l'extraordinari congost del Bon-Rebei, creat pel Noguera Ribagorçana en creuar el Montsec, separant el Montsec d'Ager (a llevant) del Montsec de Montgai (a ponent). FOTOGRAFIA 6.

\section{PARADA 10. CRUÏLlLA DE LA CARRETERA N-230 AMB LA} CARRETERA D’ESTOPANYÀ, (Pilsà, terme municipal de Benavarri, comarca de la Baixa Ribagorça). (Full 251).

Després de fer l'aturada anterior, cal seguir de nou per la carretera N-230, anant cap al Nord, amb la finalitat de trobar el trencall de la carretera que es dirigeix cap a Estopanyà. En trobar-la, prop de la cruillla farem una nova aturada, a uns $5 \mathrm{Km}$ de l'anterior.

En aquest recorregut, hem anant baixant (moll lleugerament) del Coll de Saganta, per la comarca de la Baixa Ribagorça. Inicialment haurem trobat afloraments dels materials carbonatats del Cretàcic, els quals ja pertanyen als Pirineus, on hem entrat a l'esmentat Coll de Saganta. Aquests materials són els que formen els relleus, per tot arreu.

Tot $\mathrm{i}$ així, en aquest indret hi ha uns afloraments dels materials quaternaris que formen la coberta de les dolines i del poljé de Purroi de la Solana. Així, des d'aquest lloc, podem observar la magnificència d'aquestes morfologies d'origen kàrstic, que s'estenen al llarg de 3 $4 \mathrm{Km}$. Des de la baixada del Coll de Saganta, fins al poble nou de Purroi de la Solana. FOTOGRAFIA 7.

També es pot fer una observació similar des de l'indret on farem l'aturada 12, d'aquest mateix itinerari, entre Purroi de la Solana i Lo Lloc (poble vell de Purroi de la Solana).

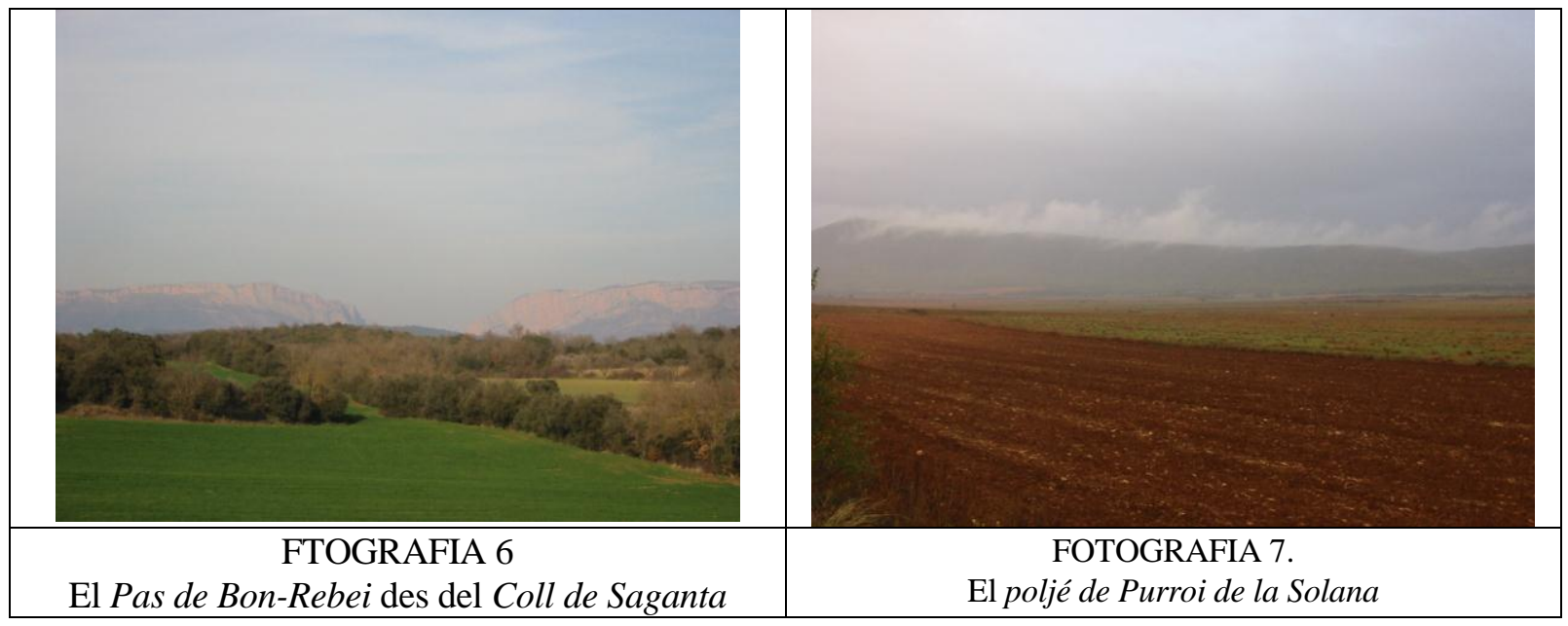

PARADA 11. LLACS D'ESTANYA, (pertanyen a l'antic terme d'Estanya, que actualment es integrat al de Benavarri, comarca de la Baixa Ribagorça). (Full 289).

Des de les immediacions de l'aturada anterior, ens cal fer una fillola. Així cal agafar la carretera que es dirigeix cap a Estopanyà'(la A-2215), però en trobar el trencall d'Estanya, ens 
caldrà agafar-lo. I, finalment. en arribar a Estanya, cal agafar el camí que s’adreça cap a Casserres del Castell, i que passa per entre mig dels estanys. Així, el recorregut haurà estat de quasi 5’5 $\mathrm{Km}$.

Tot aquest recorregut, s'efectua sempre dintre del Mantell de la Unitat de les Serres Marginals, amb afloraments de materials mesozoics, molt sovint recoberts pels "Conglomerats de Baells", de 1'Oligocè.

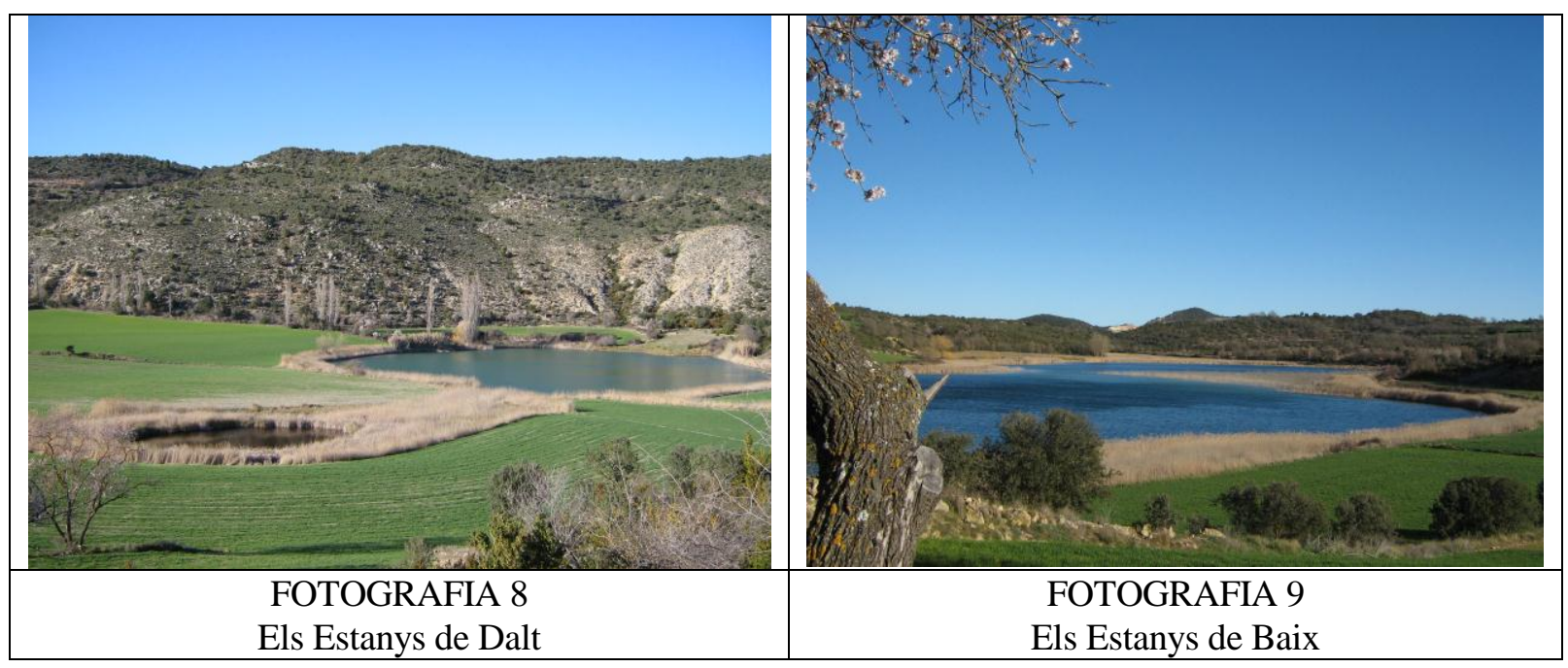

Pel que fa als estanys, cal dir que aquests es troben entre un ample aflorament dels materials guixosos i argilosos del Keuper. Aquests constitueixen un bon conjunt de llacs d'origen kàrstic. En total són quatre estanys, amb un de molt gran (1'Estany Gran de Baix), el qual es troba en èpoques de sequera, separat en dues parts, cada una de les quals correspon a una dolina. FOTO. 8 i 9.

PARADA 12 CONDICIONAL. MINA DE MANGANES DE PURROI DE LA SOLANA, (Purroi de la Solana, terme municipal de Benavarri, comarca de la Ribagorça / Ribagorza). (Full 289).

Després de fer l'aturada anterior, cal retornar cap a la carretera N-230, amb la finalitat de continuar el trajecte cap al Nord. Així, aviat s'arribarà a la part baixa de Purroi de la Solana, i més concretament a l'inici de la carretera que va a Lo Lloc. Just a l'inici es pot fer aquesta aturada a una antiga mineta de manganès, si s'escau.

Com es natural en aquest hem tornat a trobar els materials esmentats a les aturades anteriors. Tot i així, ara ens trobem davant d'un aflorament de calcàries mesozoiques del Cretàcic, sobre les quals s'ha desenvolupat una mineralització manganesífera associada a rebliments de cavitats d'origen Karstic. Concretament las mineralització es situa sobre les denominades "calcàries sorrenques del Montsec"

Es tracta d'un rebliment de quimisme Fe-Mn, amb presencia dels següents minerals de manganès: BIRNESSITA, PIROLUSITA (es el mineral majoritari de l'indici), PSILOMELANA, RAMSDOLLITA (molt minoritària), TODOROQUITA, MANGANOCALCITA y RODOCROISITA. Per d'altra part, entre els minerals de ferro es troben els següents: GOETHITA (molt abundant i sempre d'aspecte terròs, limonític), HEMATITES (molt abundant) i SIDERITA. Tanmateix es també abundant la CALCITA, 
sovint rosada.

La mina es molt petita i actualment es troba parcialment enrunada. Un aspecte de la mateixa, es pot veure a la FOTOGRAFIA 10

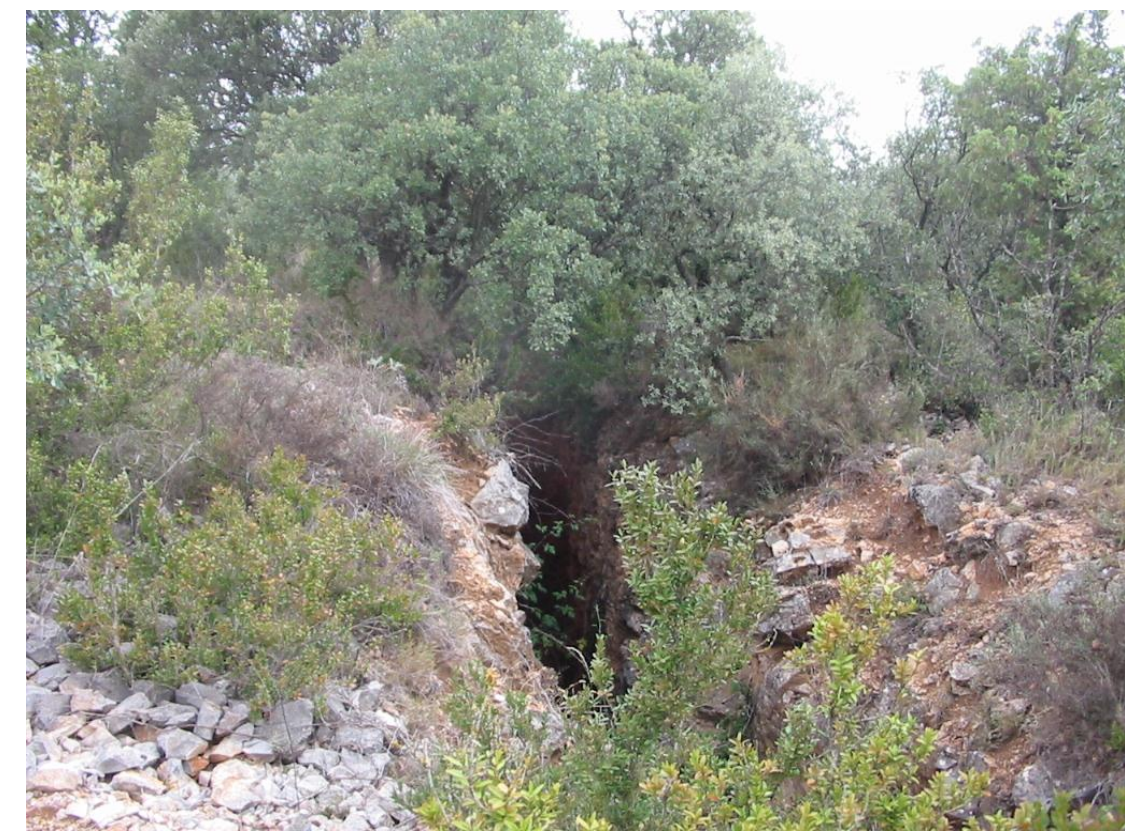

FOTOGRAFIA 11

Mina de manganès de Purroi de la Solana

EN AQUEST INDRET FINALITZA L'ITINERARI

\section{BIBLIOGRAFIA}

CALVO, M. et altri (1988).- Minerales de Aragón. Colección temas geológicos.200 pag. Zaragoza.

GUIMERÀ, J. et altri (1992).- Geologia (II), Història Natural dels Països Catalans, Vol.2, 547 pag. Enciclopèdia Catalana, S.A. Barcelona.

MATA-PERELLÓ, J.M. (1979).- Les mineralitzacions de manganès d’Estopanyà i de Natjà. Acta Geol. Hispànica, t. XIV (tom hom. al Dr. Lluís Solé i Sabarís), 4 p. Barcelona.

MATA-PERELLÓ, J.M. (1990a).- Inventario Mineralógico de la comarca de la Llitera/Litera. Revista Rodeno, $\mathrm{n}^{\circ}$ 17, 24 pag. Manresa.

MATA-PERELLÓ, J.M. (1990b).- Inventario Mineralógico de la Ribagorça Oriental/Ribagorza Oriental. Revista Rodeno, nº 18, 31 pàg. Manresa.

MATA-PERELLÓ, J.M. (1991a).- Els Minerals de Catalunya. Arxius de la Secció de Ciències, t. XCIII, 442 pag. Institut d'Estudis Catalans. Barcelona. 
MATA-PERELLÓ, J.M. (1991b).- Selecció d'Ttineraris de recerca mineralògica: Pel Baix Penedès, l'Anoia, la Noguera, la Llitera, la Baixa Ribagorça, la Cerdanya i l'Alt Urgell. Xaragall, 27, 36 pag. Manresa.

MATA-PERELLÓ, J.M. (1995).- Itinerari geològico-mineralògic entre Lleida (Segrià) i Estanya (Baixa Ribagorça), per Estopanyà (Litera-Baixa Ribagorça). Inèdit, 10 pàgines. Manresa

MATA-PERELLÓ, J.M. (1996).- Recerca geològica i mineralògica per les comarques del Segrià, Noguera, Llitera i Baixa Ribagorça: des d'Alfarràs a Peralta de la Sal, per Estopanyà. Apunts EUPM, 10 pàg.. Manresa.

MATA-PERELLÓ, J.M. (1997).- Recerca geològica i Mineralògica per les comarques de la Llitera i de la Baixa Ribagorça: des de Sant esteve de Llitera a Entença, per Peralta de la Sal i per Purroi de la Solana. Inèdit. 13 pàgines. Manresa

MATA-PERELLÓ, J.M. (1998).- Recorregut de recerca geològica i mineralògica pel Segrià, la Baixa Ribagorça i la Llitera: des de Lleida a Peralta de la Sal, revista Algeps sèrie B, $\mathrm{n}^{\mathbf{0}} 105,18$ pag. Manresa

MATA-PERELLÓ, J.M. (2002).- Recorregut de recerca geològica i mineralògica per les comarques del Segrià, de la Llitera i de la Baixa Ribagorça i la Llitera: des d’Alfarràs a Purroi i a Benavarri, revista Xaragall sèrie $\mathrm{B}, \mathrm{n}^{\circ} 236,12$ pag. Manresa

MATA-PERELLÓ, J.M. (2006).- Recorregut de recerca geològica i mineralògica per les comarques del Segrià, Llitera i Baixa ribagorça: des d'Alfarràs a Tamarit de Llitera, Baells, Estopanyà, Camporrells i Vall-de-llou- Inèdit. 12 pag. Manresa

MATA-PERELLÓ, J.M. (2007).- Recorregut de de recerca geològica i mineralògica, per les comarques del Segrià, de la Llitera i de la Baixa Ribagorça: des d’Alfarràs a Tamarit de Llitera, Saganta, Estanya i Estopanyà. Inèdit. 14 pàgines. Manresa

MATA-PERELLÓ, J.M. (2009).- Recorregut de de recerca geològica i mineralògica, per les comarques de la Llitera / Litera i de la Ribagorça / Ribagorza: des de Purroi de la Solana a Estanya, Estopanyà, Camporrells, Vall-de-llou i a Camporrells. Inèdit. 14 pàgines. Manresa

MATA-PERELLÓ, J.M. (2010).- ).- Recorregut de de recerca geològica i mineralògica, per les comarques de la Llitera / Litera i de la Ribagorça / Ribagorza: des de Baells i Natjà a Saganta, Mas Blanc, Estanya, Estopanyà, Camporrells, Vall-de-llou i a Castillonroi. Inèdit. 20 pàgines. Manresa

MATA-PERELLÓ, J.M. i MONTANÉ GARCÍA. P. (2002).- Recorregut de recerca geològica i mineralògica per les comarques del Segrià, la Llitera i la Baixa Ribagorça: des d’Alfarràs a Camporrells, a Caladrons i a Benavarri, Inèdit, 14 pag. Manresa

MATA-PERELLÓ, J.M. i MONTANÉ GARCIA,P. (2005).- Recorregut de recerca geològica i mineralògica per les comarques del Segrià, la Llitera i la Baixa Ribagorça: des d'Alfarràs a Estopanyà, a Soriana i a Benavarri. Inèdit. 10 pag. Manresa

MATA-PERElló, J.M. i SANZ BALAGUÉ, J. (1989).- Inventari Mineralògic de la 
comarca de la Llitera / Litera. Revista Terra Endins, nº 2, 32 pag. Manresa.

MATA-PERELLÓ, J.M. i SANZ BALAGUÉ, J. (1990).- Inventari Mineralògic de la comarca de la Baixa ribagorça, Revista Terra Endins, n' . 3, 27 pag. Manresa.

RIBA, O. et altri (1976).- Geografia Física dels Països Catalans, Edita. Metres, 254 pàgines. Barcelona

TAULES D'EQUVALÈNCIES DELS TERMES TOPONÍMICS UTILITZATS EN AQUEST RECORREGUT, REALITZAT PER LES COMARQUES DE LA RIBAGORÇA / RIBAGORZA I DE LA LLITERA / LITERA

\section{TOPÒNIMS EN LES \\ VARIETATS DIALECTALS DE LA ZONA}

\section{TOPÒNIMS EN LENGUIA CASTELLANA}

\begin{tabular}{|c|c|}
\hline BAIXA RIBAGORÇA & BAJA RIBAGORZA \\
\hline CAMPELL, LO & ALCAMPELL \\
\hline CASTILLONROI & CASTILLONROY \\
\hline ESTANYA & ESTAÑNA \\
\hline ESTOPANYÃ & ESTOPIÑAN DEL CASTILLO \\
\hline LLITERA & LITERA \\
\hline NATJÀ & NACHÁ \\
\hline PILSÀ & PILZAN \\
\hline PURROI DE LA SOLANA & PURROY DE LA SOLANA \\
\hline RIBAGORÇA & RIBAGORZA \\
\hline
\end{tabular}

